\title{
Os filmes de terror como alegoria para os horrores sociais
}

\author{
Jaime César Pacheco Alves dos Santos ${ }^{1}$ \\ Maíra Carvalho ${ }^{2}$
}

\section{Resumo}

A filmografia de terror do período de trinta anos que compreendeu as décadas de 1950, 1960 e 1970, acompanhou os temores da sociedade estadunidense ganharem forma à medida que os perigos se tornavam cada vez menos improváveis e cada vez mais palpáveis. Na década de 1950, o terror era algo longínquo que vinha de fora para desordenar a estrutura social da América. Nesse sentido, o filme Vampiros de Almas, de Don Siegel, sintetizou as inseguranças dos Estados Unidos de se render ao regime comunista e à paranóia vigente com a caça às bruxas comandada pelo Senador McCarthy. A década de 1960 começou então com a promessa de quebra dos sonhos dourados almejados na década anterior. A suplantação do velho pelo novo é um dos sentimentos presentes no filme $A$ Noite dos Mortos-Vivos, de George A. Romero, que retratava as ideias retrógradas como mortos que insistiam em se manter ativos. A aproximação do terror, enfim, atingiu as famílias na década de 1970, em um já esperado choque de gerações que o filme O Exorcista, de William Friedkin, representou ao mostrar uma mãe que já não sabia lidar com a própria filha. Usando de alegorias, esses filmes e alguns outros desse

1 Formou-se em 2009 no curso de Comunicação Social com habilitação em Publicidade e Propaganda. Escritor, tem dois contos publicados em coletâneas destinadas a novos talentos. Contato: jaimecsarp4@gmail.com.

2 Historiadora, formada pela Universidade de Brasília em 2002. Entre 2002 e 2004, pós-graduou-se em História e Estética do Cinema na Universidade de Valladolid, na Espanha. Atualmente complementa seus estudos com uma Especialização em História da Arte. Em fevereiro de 2006, foi contratada para lecionar as disciplinas de Redação e Produção Audiovisual no curso de Comunicação do Centro Universitário UniCEUB. Em 2009, foi contratada para dar aulas no Iesb de Cenografia e Figurino no curso de Cinema e Mídias Digitais. Desde 2001, participa de produções teatrais, publicitárias e cinematográficas como Produtora, Diretora de Arte, Figurinista e Cenógrafa. Já participou de mais de 20 produções cinematográficas, dezenas de produções publicitárias e produziu espetáculos teatrais de repercussão nacional. Contato: mairacarvalho@gmail.com. 
período estreitaram as relações entre ficção e realidade, imprimindo um aspecto documental a essas produções.

Palavras-chave: Cinema. Terror. Alegoria. Estados Unidos.

\section{Introdução}

No cinema, realidade e fantasia são polos opostos que se complementam em uma relação de dependência essencial para a difusão da sétima arte entre as multidões. Desde sua primeira exibição, quando a realidade de um trem vindo em direção à plateia causou pânico entre os telespectadores desavisados à magia que se desenrolava, ficou explícita a necessidade do cinema de se alimentar de fatos reais e corriqueiros para atingir as grandes massas.

Essa forma diferente de retratar a realidade fez do cinema um espelho dos acontecimentos desenvolvidos em cada década. Nesse contexto, os filmes dramáticos aparecem ao longo da história do cinema como representações mais confiáveis da realidade. A valorização dos filmes dramáticos se deu por conta da imediata identificação do público com as histórias que não precisavam se apoiar em estereótipos e se passavam em um mundo mais real e reconhecível.

Entre os gêneros cinematográficos, o terror é o mais subestimado. Visto muitas vezes como território para mentes perturbadas, o terror se apropria de alegorias para, com eficiência, retratar os acontecimentos de sua própria maneira. Usando o medo como inesgotável fonte de ideias, o terror se fortaleceu como gênero narrativo ao mesmo tempo envolvente e repulsivo, gerando histórias que se equilibravam na corda bamba do socialmente aceito e do tabu.

Tendo em vista a maneira singular com que o gênero terror enxerga a realidade, o presente trabalho se dispõe a analisar como os filmes de terror representaram os períodos em que foram produzidos - as décadas de 1950, 1960 e 1970. Para isso, um filme de terror representativo de cada década será analisado e comparado aos acontecimentos mais marcantes da época em que foram realizados. $\mathrm{O}$ foco do 
trabalho será a sociedade estadunidense, tendo em vista que os filmes analisados foram produzidos em Hollywood.

Os filmes escolhidos para a análise se destacam entre as demais produções do gênero pelo poder de manterem-se críveis e cultuados mesmo com o passar dos anos. Ainda objetos de análise em todo o mundo, os filmes selecionados tiveram grande impacto na cultura popular, alcançando grande sucesso na época em que foram lançados e nos anos posteriores. O filme escolhido para representar a filmografia de terror dos anos de 1950 foi Vampiros de Almas, 1956, de Don Siegel. Os anos de 1960 foram representados por A Noite dos Mortos-Vivos, 1968, de George A. Romero, e os anos de 1970, por O Exorcista, 1973, de William Friedkin.

Partindo desse ponto, a questão que norteará esse trabalho é: Quais são as alegorias usadas pelo cinema de terror e como elas representam os temores da sociedade?

Para responder à questão levantada, o trabalho se apoiou em pesquisas bibliográficas referentes ao cinema como meio de representação, na trajetória do terror como gênero narrativo e na sua relação com o medo. Essas pesquisas tiveram como objetivo apresentar as formas com as quais o cinema reproduz a realidade nas salas de exibição. No contexto dos filmes de terror, deu-se ênfase às formas de representação usadas por eles para passar sua mensagem, a fim de que o texto e o subtexto sejam mais bem compreendidos.

\section{Década de 1950: a onda vermelha ameaça a prosperidade americana}

O fim da Segunda Guerra Mundial deixou marcas visíveis na economia do planeta e redefiniu os centros detentores de poder. Em meio às mortes e perdas, os Estados Unidos foram a única nação a sair fortalecida da guerra, exibindo um grande poderio militar e uma economia estável (SELLERS; MAY; McMILLEN, 1990, p. 363). 
O período do pós-guerra foi de agradável estabilidade para a sociedade estadunidense. A taxa de natalidade, que havia recuado nos anos 1930, subiu na década de 1940 e se manteve por toda a década de 1950. A "explosão de nascimentos" forçou uma mudança de hábitos, sociais e econômicos. A classe média trocou a agitação dos centros urbanos pela tranquilidade dos subúrbios. O sonho americano ganhou contornos nítidos com a casinha branca com gramado verde na frente.

Os Estados Unidos receberam uma overdose de boas notícias, uma série de eventos encadeados que tinham como resultado uma prosperidade constante, pois o aumento demográfico implicava no aumento do consumo, que implicava no aumento de postos de emprego, que implicava em mais prosperidade, que implicava em mais crescimento demográfico (SELLERS; MAY; McMILLEN, 1990, p. 386).

Mas, por baixo da fachada de euforia, havia certo grau de preocupação. Em 1949, a União Soviética explodiu sua primeira bomba atômica. O acontecimento pegou o governo americano de surpresa, pois as previsões eram de que os soviéticos só teriam tecnologia para tal feito em 1954. Os governantes chegaram à conclusão de que a tecnologia das bombas tinha sido entregue por espiões. A paranoia comunista, que estava sendo ensaiada desde o fim da Segunda Guerra Mundial, atingiu os Estados Unidos (FERREIRA, 1989, p. 77).

A cruzada americana contra os comunistas teve no senador Joseph Raymond McCarthy sua figura mais emblemática, mas os esforços do governo estadunidense de identificar e punir possíveis comunistas infiltrados já existiam antes da ascensão de McCarthy. Em 1945, tiveram início as audiências da Comissão de Atividades Antiamericanas (HUAC), responsável por identificar movimentos subversivos. As audiências da HUAC giravam em torno de alegadas infiltrações de comunistas em sindicatos e no cinema e uma possível espionagem atômica que envolveria agentes soviéticos escondidos nos Estados Unidos com intuito de roubar tecnologia bélica. As audiências continuaram ocorrendo mesmo após a morte de McCarthy em 1957 (FERREIRA, 1989, p. 14-22).

McCarthy gozou de grande popularidade no começo dos anos de 1950, usando o medo dos americanos de uma possível invasão comunista para se pro- 
mover. Em um jantar oferecido por seu partido, ele alegou estar de posse de uma lista com mais de duzentos nomes de comunistas infiltrados no Departamento de Estado, embora, hoje em dia, pairem dúvidas sobre a veracidade das afirmações. As declarações de McCarthy, falsas ou não, fizeram dele um astro ante a amedrontada sociedade estadunidense.

Em tempos normais, acusações irresponsáveis de um senador obscuro pouca atenção teriam merecido da imprensa e do país. Mas não eram tempos normais. Naquele mês de fevereiro de 1950, a nação já estava à beira da histeria, com uma substancial contribuição dos jornais (FERREIRA, 1989, p. 99-100).

McCarthy ganhou status logo após a condenação do diplomata Alger Hiss, em janeiro de 1950, sob acusação de perjúrio, mas com conotação de espionagem. O nome de Hiss virou sinônimo de traição e iniciou-se uma verdadeira cruzada para banir possíveis comunistas infiltrados em todo o país. Um grande número de pessoas perdeu o emprego por conta de denúncias anônimas, ninguém mais era inocente, e a mais simples dúvida a respeito do acusado era quase uma condenação (FERREIRA, 1989, p.80).

\section{1 "O inferno são os outros"}

A ação de Vampiros de Almas se concentra na cidade interiorana de Santa Mira, que vira palco de acontecimentos inexplicáveis. Esses acontecimentos são presenciados pelo médico Miles Bennell que descobre, junto com a namorada Becky, uma conspiração alienígena para substituir humanos por réplicas sem emoção. Jack - amigo de Bennell -, , Ira e Wilma - familiares de Becky -, sucumbem ao aliens, assim como toda a cidade, deixando os dois sozinhos na luta contra os invasores.

Há uma cena em Vampiros de Almas na qual é permitido ao público visualizar como seria o mundo se a doutrina comunista se espalhasse. Na praça da pequena cidade de Santa Mira, uma multidão homogênea e sem emoção cerca um caminhão cheio dos casulos que se tornariam sósias dos seres humanos, obede- 
cendo às ordens de um chefe de polícia. Enclausurados em um consultório médico, Miles Bennell e sua namorada Becky, encaram aterrorizados a formação desse novo mundo.

Emblemático em seu ataque ao comunismo, Vampiros de Almas atinge na cena descrita acima seu ápice como filme propagandista e exemplifica o medo de uma sociedade que vivia eufórica com o nascimento do consumismo e com as delícias de um período que exalava prosperidade. A ideia de ser mais um, de ser igual aos outros e de não se destacar era extremamente contrária ao estilo de vida estadunidense, e por isso precisava ser combatida.

Embora a história original tenha sido imaginada por um escritor que se esquivava de polêmicas políticas, nas mãos de um diretor de direita, Vampiros de Almas usou invasores espaciais desprovidos de emoções como alegoria para os comunistas que o Governo dos Estados Unidos combatia.

A trama de Vampiros de Almas se concentra em uma cidade do interior dos Estados Unidos, como muitas das histórias catastróficas daquele período. Nada melhor que uma cidade pacata e agradável para transmitir a ideia de prosperidade. Jack Finney, autor do livro que inspirou o filme, não se cansa de atribuir à pequena cidade de Santa Mira uma inequívoca aura de placidez.

\begin{abstract}
A nota principal que Finney faz soar repetidas vezes nesses primeiros capítulos é tão baixa que em mãos menos hábeis se tornaria insípida: mas é agradável. [...] as coisas em Santa Mira, conta-nos ele, não são grandiosas, não são selvagens nem loucas, não são terríveis nem aborrecidas. As coisas em Santa Mira são agradáveis (KING, 1989, p. 337).
\end{abstract}

Don Siegel, ainda que não explore demoradamente essa característica, não se priva de mostrar Santa Mira como um lugar agradável. Ao buscar Bennell na estação de trem, a enfermeira atualiza-o sobre os pacientes com o tom de intimidade de quem mantém relações fora do consultório. A cidade se mostra prosaica e convidativa como todas as cidades interioranas mostradas no cinema de Hollywood; um cenário condizente com os ideais propagados pelo american way of life. 
Mas há uma agitação no ar que é perceptível. Siegel nunca deixa que o ambiente calmo o iluda. Quando Bennell vê um garoto fugindo da própria mãe, o sinal de alerta do público é ligado. Logo ali, no começo do filme, o espectador sabe que algo está errado, embora não saiba exatamente o que é. Deixado no escuro, o espectador já se arma contra a ameaça vindoura, sem nem saber do que se trata.

Quando Bennell sabe pela namorada Becky que sua prima Wilma afirma que o tio Ira não é a mesma pessoa, o cenário começa a se delinear. Bennell visita Wilma e Ira, apenas para descobrir que o homem não está em nada diferente do que ele lembrava. Wilma, no entanto, mantém sua posição e diz que tudo na aparência de Ira está idêntico, mas tem algo nele que é diferente.

Com essa observação, Wilma mostra que a mudança de Ira não foi externa, mas interna. Ele já não é o mesmo, pois já não pensa como pensava, não tem os mesmos princípios, as mesmas ideias políticas. E isso é o pior, pois apesar de ainda ser completamente identificável como Ira, ele já não pensa como ela, e é isso que desencadeia a mudança.

O uso de seres do espaço foi uma constante nos filmes de terror dos anos de 1950. Com uma estrutura social e econômica firme e próspera, a sociedade estadunidense não tinha o que temer, "o inferno eram sempre os outros". O terror que vinha de fora era o que assustava, pois ameaçava o estilo de vida confortável que a sociedade desfrutava. Os extraterrestres de Vampiros de Almas queriam exatamente isso, uma sociedade igual, onde todos fizessem, sentissem e pensassem as mesmas coisas. E é possível ler nas entrelinhas desse discurso uma palavra: comunismo.

A ascensão do Senador McCarthy ao poder foi acompanhada de uma boa dose de paranoia; e o filme não abandona esse aspecto. Ao contrário, abraça-o desde a primeira cena que mostra o doutor Miles Bennell diante das autoridades, tentando explicar a trama dos invasores espaciais.

O conceito do inimigo sem rosto, e por isso mesmo difícil de ser combatido, adiciona mais elementos paranoicos ao filme. Em nenhum momento a verdadeira aparência dos invasores é mostrada. Quando Bennell e seu amigo Jack conseguem 
abrir um dos casulos que carregam os alienígenas, encontram um corpo disforme, indefinível. Ele só se define ao assumir as características dos humanos que serão substituídos, e aí já é tarde demais. Repetindo a ideia do período de caça às bruxas, todos eram culpados até que provassem o contrário.

A máxima do "não confie em ninguém" é insistentemente repetida ao longo da segunda parte do filme, quando Bennell descobre que todas as pessoas em que achava que podia confiar foram substituídas por réplicas em uma sucessão desesperadora. Primeiro, os atendentes de um posto de gasolina que colocam casulos no porta-malas de seu carro; depois sua enfermeira, que realiza em sua casa uma reunião com outras réplicas; seu amigo Jack é o próximo e, por fim, sua namorada, Becky. Tal como a imagem que McCarthy pintou de si mesmo, Bennell aparece como o herói solitário que precisava alertar as pessoas sobre o perigo que as aguarda: o terror dos comunistas do espaço.

Siegel declarou que em Vampiros de Almas fez um filme sobre a Ameaça Vermelha. Uma das cenas que corroboram essa afirmação é uma das poucas que não existem no livro de Finney. Após se livrar da perseguição dos alienígenas, Bennell grita para os carros de uma autoestrada: "Eles já estão aqui! Vocês serão os próximos!” Aqui, Bennell berra o que muitos americanos queriam. Com a suspeita de espiões comunistas infiltrados nos Estados Unidos, a ideia de que a União Soviética queria espalhar o comunismo para todos os cantos do mundo e o medo de que conhecidos estivessem aderindo àquela nova política, as afirmações de Bennell não soavam nada absurdas.

Vampiros de Almas foi um filme que representou como poucos a atmosfera alarmista de sua época, mas a alegoria usada no filme é maleável e adaptável. Prova disso são as novas versões da história de Finney que chegaram ao cinema em épocas distintas, mas sempre tiveram o poder de representar os medos daqueles períodos.

Em Invasores de Corpos (1978), a alegoria de seres do espaço que tomavam o lugar dos humanos foi empregada para mostrar os conflitos e mudanças sociais da década de 1970. Já a refilmagem homônima de 1990, usou como cenário uma 
base militar para expor os perigos do terrorismo. A mais recente adaptação da obra de Finney, Os Invasores (2008), abraça o medo dos Estados Unidos de um ataque biológico terrorista em voga desde os atentados ao World Trade Center em 11 de setembro de 2001. O filme transforma os invasores alienígenas em um vírus que se espalha pelo mundo, mudando o comportamento das pessoas (DIRKS, 2009).

\section{Década de 1960: hora de rever conceitos}

A década de 1960 revelou para a sociedade estadunidense seus conflitos internos e a necessidade de dar voz às minorias. Ainda sobre o efeito etílico da prosperidade econômica dos anos de 1950, os Estados Unidos viram os primeiros anos da década de 1960 com otimismo e esperança, e o novo Presidente John F. Kennedy personificava esse período com sua juventude e disposição (SELLERS; MAY; McMILLEN, 1990, p. 395).

Mas, ao decorrer da década, vários conflitos internos abalaram a tranquilidade aparente e levaram a sociedade estadunidense a rever seus conceitos. $\mathrm{O}$ mais significativo deles foi a luta dos negros por direitos iguais. Na década de 1960, a segregação ainda era uma realidade nas cidades dos Estados Unidos, e foi nesse cenário que Martin Luther King Jr. se destacou.

Com movimentos pacíficos, como um boicote contra os ônibus que durou quase um ano, a luta por direitos iguais atingiu todo o país e alcançou vitórias significativas contra a segregação nos meios de transporte público e nas Universidades, mesmo enfrentando uma oposição branca violenta que atacava os negros e as suas propriedades (SELLERS; MAY; McMILLEN, 1990, p. 397-398).

A militância negra em prol de direitos civis inspirou uma série de manifestações pelos Estados Unidos, mostrando a insatisfação de determinados grupos com o tratamento a eles destinado. O feminismo, adormecido desde a década de 1920, ressurgiu junto com a vontade das mulheres de redefinir seu papel na sociedade. 
Embora o ressurgimento conseqüente do feminismo parecesse pegar a nação de surpresa, as queixas ventiladas eram mais do que justificadas. A Décima Nona Emenda concedera o direito de voto às mulheres, mas não lhes redefinira o papel no lar e na sociedade. Nem lhes abrira caminho à igualdade educacional e de emprego (SELLERS; MAY; McMILLEN, 1990, p. 409).

Assim como aconteceu com os negros, a causa das mulheres enfrentou oposição ferrenha das camadas mais conservadoras da sociedade estadunidense. Mas mesmo com a oposição, o movimento feminista colheu frutos significativos. Durante a luta, o movimento recrutou mais adeptos e, em 1964, o Título VII da Lei dos Direitos Civis "proibiu não só a discriminação nos empregos por motivo de raça como também de sexo" (SELLERS; MAY; McMILLEN, 1990, p. 410).

Se o feminismo e a militância dos negros por direitos iguais tiveram contornos políticos, o movimento hippie teve efeito na esfera social. Iniciado nas cidades costeiras dos Estados Unidos, com destaque para São Francisco, o movimento hippie se alastrou pelas demais cidades do país e pelo mundo (COELHO, 2003, p. 53).

Os hippies pregavam um estilo de vida mais livre e pacífico, longe das convenções e tabus. Partidários da ideia "Paz e Amor", os hippies se posicionaram contra a interminável Guerra do Vietnã (1959-1975) e deixaram marcas na moda (roupas coloridas e cabelos desgrenhados), na música (rock and roll) e no comportamento sexual (sexo casual) (SELLERS; MAY; McMILLEN, 1990, p. 411).

Os anos de 1960 mostraram uma sociedade inquieta e disposta a mudanças, embora ainda em confronto com os ideais tradicionais na década de 1950. Os filhos do "Baby Boom" da década de 1950 haviam crescido e buscavam coisas diferentes de seus pais, numa prévia do choque de gerações que ia explodir na década de 1970.

\subsection{Fora com o velho, viva o novo!}

O início de A Noite dos Mortos-Vivos apresenta os irmãos Bárbara e John visitando o túmulo do pai no primeiro dia de verão. Inesperadamente, eles são 
atacados por um morto-vivo que mata John, mas deixa Bárbara escapar. Assustada, Bárbara se esconde numa casa abandonada e se junta a outros refugiados: o jovem Ben, o casal Cooper com sua filha machucada, Karen, e os namorados, Tom e Judy. Juntos, eles tentam resistir aos ataques dos mortos-vivos.

Os monstros e alienígenas que invadiram os filmes hollywoodianos na década de 1950 entraram em extinção nos anos de 1960. Ameaças interplanetárias e seres de outras galáxias já não causavam o mesmo efeito numa audiência que via os anos da Segunda Guerra Mundial e os espiões comunistas como assuntos de um passado distante.

Já no início dos anos de 1960, o público estadunidense descobriu que nem de longe os monstros eram tão assustadores quanto as agitações políticas e sociais que tomavam conta do país. E se antes a ameaça de mudança das estruturas sociais era externa, agora partia de dentro dos Estados Unidos, com a insatisfação das minorias com o status quo.

Na cena inicial de A Noite dos Mortos-Vivos, Bárbara e John visitam o túmulo do pai, uma representação simples do novo suplantando o velho. O antigo tem que dar lugar ao jovem, a geração anterior tem que sair de cena para que uma nova continue a comandar o mundo do seu jeito.

Esse primeiro contato com a morte mostra a vocação do filme, como uma boa história de terror, de mexer com os tabus. Longe de ser uma experiência pessoal, ainda que sedutoramente macabra, a morte virou algo a ser evitado na sociedade ocidental moderna, já que, constantemente, lembrar o homem de sua mortalidade é uma "meditação metafísica sobre a mortalidade da vida" (CAETANO, 2009). Ao escancarar a faceta da morte, $A$ Noite dos Mortos-Vivos vira um incômodo lembrete, um inevitável vislumbre do futuro.

O primeiro exemplo, naturalmente, é A Noite dos MortosVivos, em que nosso horror à morte é explorado a um ponto em que muitas audiências acharam o filme quase insuportável. [...] o filme circula em torno de seu ponto de partida sempre e mais e a palavra-chave do título do filme não é vivo e sim morto (KING, 1989, p. 145). 
Quando chega ao nível do tabu, o filme extrapola no que se trata da morte: túmulos violados, mortos incinerados e com os cérebros destruídos. Vai contra toda e qualquer ideia de descanso tranquilo, da boa morte.

Os mortos ressuscitados no filme são uma alegoria para as ideias retrógradas que insistiam em se manter na ordem do dia na progressista década de 1960 . Os mortos são mostrados como maltrapilhos e lerdos; não parecem dispor de vivacidade e paixão, contrastando com o modo violento e agressivo com o qual eles atacam suas vítimas.

Quando foge do morto-vivo que a ataca no cemitério e se entrincheira em uma casa, Bárbara se mostra disposta a resistir ao velho, embora assustada e abalada. Fruto de uma época de revoluções e protestos, A Noite dos Mortos-Vivos apresenta a resistência como única forma de sobreviver aos valores antigos. Trancados na casa, os sobreviventes procuram não só impedir a entrada dos mortos-vivos, mas achar um meio de exterminá-los, pois essa é a única maneira de alcançar a segurança.

Visto por esse ponto, não chega a surpreender o momento em que Ben descobre que os zumbis têm medo do fogo. Seja como uma representação da luz ou da paixão, o fogo causa repulsa aos mortos-vivos, pois representa tudo o que os antigos querem impedir que os jovens apreendam: o conhecimento e o engajamento.

Ao apresentar Ben como o grande protagonista da história, o filme se mostra mais uma vez sintonizado com as agitações da época. A luta dos negros por direitos iguais foi a grande luta social dos anos de 1960, e ao apresentar um negro como o líder da resistência dos não-mortos, Romero não desmerece essa luta.

Ben é a personagem mais atuante do filme. Sua primeira aparição até carrega um ar místico e reverencial: ele aparece, surgindo de uma luz ofuscante que, na verdade, são os faróis de seu carro, e salva Bárbara da morte certa. São dele as ideias que mantêm os resistentes seguros por mais tempo, é ele quem procura meios de se manter a salvo e é ele quem morre com um tiro por lutar pelo que acredita. Não muito diferente de Martin Luther King Jr. 
As mulheres, outra minoria que lutou por igualdade nos anos de 1960, não são representadas com essa reverência. Bárbara se mostra assustada e indecisa, assim como as outras mulheres da casa, quase como se a situação não fosse com ela. Embora todas as mulheres presentes no filme, eventualmente, exerçam papel ativo na luta em momentos decisivos, elas são sempre derrotadas pela emoção, e a luta pela causa perde espaço.

A cena da morte de Bárbara representa essa ideia da mulher como um ser extremamente emocional e não racional. Ao ver a Sra. Cooper ser agarrada pelos mortos-vivos, Bárbara sai de seu estado catatônico para protegê-la, mas, ao descobrir que seu irmão se transformou em um morto-vivo, Bárbara se deixa levar e, ainda que lute, no final se torna um deles.

Além de Ben e Bárbara, fazem parte da força de resistência dois casais, um de jovens namorados e outro de adultos casados e com uma filha doente. A dinâmica do filme muda no momento em que essas novas personagens se revelam. Descobrimos que elas estavam o tempo todo no porão e, embora ouvissem os gritos de desespero e as lutas, não subiram para ajudar. Ben imediatamente entra em conflito com o Sr. Cooper, um homem tradicional e tacanho, e novamente o conflito de gerações e ideias é escancarado.

Tanto Cooper quanto Ben desempenham papéis de liderança em seus respectivos grupos, o que cria atritos quando se juntam. Enquanto Cooper mantém uma postura acomodada, Ben apresenta uma postura progressista. A postura de Ben é mais atraente para os jovens, e o casal de namorados logo se rende a ela. Cooper, por outro lado, se mantém resistente e é morto por Ben. A militância vence o comodismo.

Ainda falando de Cooper, ele e a família protagonizam a cena mais controversa e forte do filme. Após levar um tiro de Ben, Cooper se arrasta até o porão onde é devorado pela filha, que fora transformada em uma morta-viva. Quando a Sra. Cooper também busca refúgio no porão, é assassinada pela filha. Nesse momento, a Sra. Cooper volta a se harmonizar com a família, uma vez que vinha sendo tomada pelas ideias progressistas de Ben. A emoção aparece novamente como ponto fraco da mulher, quando a Sra. Cooper se rende à filha sem lutar. 
A Noite dos Mortos-Vivos, um filme independente de 1968, sintetizou o horror da mudança, a resistência jovem e a insistência das velhas convenções de se manterem ativas com uma premissa muito simples: Mortos recentes se levantam das tumbas e atacam os vivos.

\section{Década de 1970: os caretas contra-atacam}

Se a década de 1960 foi marcada por uma aura progressista e renovadora, a década seguinte fez o caminho inverso, foi uma época de repressão. Com um governo republicano e tradicional, a sociedade estadunidense lutou para manter viva a chama do conservadorismo tão em baixa nos anos de 1960.

Os movimentos sociais, longe de buscarem a integração, pregavam a segregação pondo em risco as conquistas da década anterior. Cruzadas contra o feminismo, a homossexualidade e o direito das minorias foram travadas por todo o país. Militantes brancos insatisfeitos com os rumos das ações pró-direitos civis alegavam que os progressos com relação às minorias implicavam em uma "discriminação ao contrário”. Os direitos dos homossexuais também eram atacados por movimentos que levantavam a bandeira da moral e dos bons costumes. Tendo como principal porta-voz Anita Bryant, a luta contra os direitos civis dos homossexuais virou uma espécie de caça às bruxas, com ações como a Proposta 6 - não aprovada por voto popular (SELLERS; MAY; McMILLEN, 1990, p. 420).

O feminismo sofria do mesmo mal que o atacava na década anterior: movimentos que iam contra seus ideais e desprezavam sua luta. A diferença é que, na década de 1970, esses movimentos eram formados e liderados por mulheres conservadoras e tradicionais.

Organizações de mulheres conservadoras - como o Feminilidade Fascinante e o Mulher Total - emergiram em fins da década para combater os objetivos do movimento de libertação feminina. Apresentando-se como "pró-família" e "contra a libertação", elas se opuseram à Emenda dos Direitos Iguais (ERA) [...] sobre o fundamento duvidoso de que fomentaria os banheiros unissex, a convocação 
das mulheres para o serviço militar e a homossexualidade (SELLERS; MAY; McMILLEN, 1990, p. 420-421).

Mesmo com oposição, o movimento para instituir a igualdade de direitos entre homens e mulheres se fortaleceu em 1974 com a aprovação da Lei de Igual Oportunidade de Crédito, "que prescrevia igual acesso a empréstimos bancários e cartões de crédito". Mas esses avanços não descartaram a discriminação contra as mulheres no trabalho. Elas ainda eram empregadas em serviços subalternos e ganhavam menos que os homens, mesmo quando assumiam cargos de chefia. As mulheres também representavam a maioria na chefia de um novo tipo de família, àquela formada por um único progenitor. $\mathrm{O}$ resultado da junção desses elementos foi aumento no número de famílias pobres nos Estados Unidos (SELLERS; MAY; McMILLEN, 1990, p. 420).

Com as taxas de natalidade em queda, a população estadunidense era mais velha na década de 1970 em comparação à década anterior. Os jovens de 1960 cresceram e abandonaram os ideais da época "Paz e Amor", pararam de pensar no coletivo e passaram a desenvolver um pensamento mais narcisista, pressagiando, assim, um inevitável conflito de gerações.

Os sinais desse choque de gerações já podiam ser sentidos no meio da década de 1960 e se estenderam até o início da década de 1970. A quebra de tabus modificou o comportamento dos jovens, para o horror dos pais que já não reconheciam os próprios filhos.

Aquilo foi mais que uma diferença de gerações. As duas gerações [...] estavam se movendo ao longo de camadas opostas da consciência social e cultural, compromisso e mesmo definições de comportamento civilizado. O resultado não foi tanto um terremoto quanto foi um abalo no tempo. (KING, 1989, p. 184)

Os problemas sociais, econômicos e a insatisfação dos jovens na década de 1970 foram os ingredientes necessários para a explosão do Punk Rock nos Estados Unidos. Surgido na cena underground de Londres, o movimento Punk chegou aos Estados Unidos, conclamando os jovens a fazerem tudo diferente. Em uma sociedade que se mostrava contrária às mudanças, a juventude se refugiava nas músicas 
agressivas, adotando comportamento desdenhoso e arrogante ao que era antigo (SEVEN, 2007).

O abuso com relação às drogas foi outro fator marcante na década de 1970, principalmente entre os jovens. Glamourizadas, as drogas se tornaram um problema a ser combatido, coisa que não havia acontecido na década anterior. As estatísticas comprovavam o aumento acelerado no uso de drogas. Em 1973, o número de pessoas que admitia ter usado maconha era de $12 \%$, esse número dobrou em um período de quatro anos. Cada vez mais jovens se sentiam atraídos não só por maconha e LSD, mas também por drogas mais pesadas. Pesquisas apontavam que isso começava a se tornar uma preocupação familiar. Em 1978, 66\% dos pais entrevistados consideravam a maconha um problema nas escolas, e 35\% tinham a mesma opinião em relação a drogas mais pesadas (ROBINSON, 2002).

\subsection{O Exorcismo}

Nas décadas que se seguiram à Segunda Guerra Mundial, a sociedade estadunidense se deparou com o medo de uma forma muito pessoal, vendo os perigos e ameaças chegarem cada vez mais perto. O Exorcista marca a década em que o medo estava tão próximo e palpável que era impossível se tornar incólume a ele. $\mathrm{O}$ terror estava dentro de casa, esperando para acontecer.

O Exorcista acompanha as tentativas da atriz Chris McNeil de livrar a filha adolescente, Regan, do que ela acredita ser uma influência demoníaca. Após fracassada intervenção de uma junta médica, Chris procura ajuda do padre/ psiquiatra Damien Karras. Convencido que a garota está realmente possuída, Karras pede a ajuda de padre Merrin, um experiente exorcista, para juntos realizarem o ritual.

Usando a possessão demoníaca como alegoria, O Exorcista destaca uma casa de família como cenário para a batalha de gerações que se deu nos anos de 1970. O conflito dos velhos contra os novos ganhou contornos épicos, sendo representando pelo eterno embate do bem contra o mal. 
Esse filme, entretanto, trata essencialmente das explosivas mudanças sociais [...] Foi um filme para todos aqueles pais que sentiram, numa espécie de terror e agonia, que estavam perdendo seus filhos e não podiam compreender por que ou como isso estava acontecendo (KING, 1989, p. 185).

Em A Noite dos Mortos-Vivos, esse conflito também é evidenciado, mas do lado contrário. Enquanto em 1960, os jovens viam nos mais velhos uma ameaça às suas ideias de agregação e mudança, nos anos de 1970 eram os mais velhos que se sentiam acuados por uma juventude insatisfeita e incompreendida, que descarregava suas frustrações em drogas pesadas e comportamentos destrutivos.

A imagem dos jovens em $O$ Exorcista, quando não é inexistente, nunca é positiva. O elenco é quase inteiramente formado de adultos, a única personagem com pouca idade no filme é Regan. Apresentada como uma criança amorosa e fácil de relacionar, Regan muda drasticamente de comportamento ao ser possuída pelo demônio, o que acontece depois de seu aniversário de 12 anos, ou seja, quando se inicia sua jornada pela adolescência.

Ainda nos momentos de calmaria do filme, a chegada da adolescência é marcada pelo início da dissociação da criança à família. Antes restrito à mãe e aos empregados da casa, o círculo de amizades de Regan se expande quando ela passa a ter contato com o Capitão Howdy, uma entidade que se comunica com ela por meio de um Oujiva Board. Quando Chris tenta se comunicar com a entidade, é repelida com certa violência. O novo amigo de Regan deixa claro que não tem assuntos para com a mãe dela, que aquela nova relação vai se desenvolver entre eles dois, sem a interferência de Chris.

Capitão Howdy se torna a influência negativa, o horror de todos os pais. Quando logo após, um padre se horroriza ao ver a imagem da Virgem Maria violada, não é difícil associar aquele ato a jovens vândalos e desrespeitosos, jovens completamente influenciados pelas más companhias.

Regan deixa de ser um sonho de menina para se transformar no pesadelo de todas as famílias. A nova Regan representava o medo de todos os pais de acordar um belo dia e descobrirem que, enquanto estavam ausentes, seus filhos haviam se 
tornado viciados em uma das drogas pesadas que espreitavam os adolescentes até mesmo no colégio.

Os sinais da possessão são exibidos ao longo do primeiro ato do filme e mostram Regan incomodada com sua cama, adquirindo uma linguagem obscena e agressiva e, por fim, atacando os mais velhos. Esses ataques são, para Chris, os maiores indicativos de que Regan não está bem, pois demonstra a perda do controle, o fim da autoridade dos mais velhos sobre os mais novos.

Embora Regan agrida e ofenda os adultos que a rodeiam no decorrer do primeiro ato, é sua postura indiferente e atrevida que faz a mãe se convencer da mudança em curso. Regan demonstra essa postura durante uma festa que a mãe oferece em sua casa. Desobedecendo Chris, Regan aparece na festa, um lugar onde não deveria estar, e se põe diante do grupo de adultos reunidos, sem cuidados. "Você vai morrer lá em cima", dispara a garota para um dos convidados, um astronauta, para logo depois urinar no tapete sem se importar com o horror que causa nos outros. Regan já não respeita os mais velhos.

O Exorcista não só abala as estruturas de poder entre jovens e velhos, mas também mostra o homem indefeso ante o desconhecido. $\mathrm{O}$ medo do desconhecido é o mais primitivo do homem, e foi se dissipando com o avanço da ciência, que tinha uma explicação para tudo. A fé de Chris na ciência, entretanto, é abalada quando as respostas que obtém para o problema da filha não são satisfatórias. No filme, quando uma junta de médicos apresenta o exorcismo como uma possibilidade para Regan, o racionalismo se curva ao misticismo, e os medos primitivos afloram.

A ficção de horror constantemente usa o expediente da quebra de tabus para atingir seu intuito de assustar. Em O Exorcista, mesmo se a alusão ao desrespeito fosse retirada, a sexualidade agressiva dos jovens seria suficiente para deixar o público estarrecido. Presente em todas as etapas da possessão, a sexualidade gritante de Regan ultraja e horroriza num crescente aterrador: ela usa palavras chulas 
para designar suas partes íntimas, se masturba na frente da mãe e dos médicos e convida o padre Merrin para o sexo.

O momento mais marcante do filme sintetiza a transformação da criança inocente na jovem problemático. Nessa cena, Chris é atraída pelos gritos de Regan, entra no quarto da filha e se depara com uma cena assustadora. Regan se masturba violentamente com um crucifixo, gritando blasfêmias e coberta de sangue. Ao tentar tirar o crucifixo de Regan, Chris tem a cabeça impelida para os órgãos genitais da filha, que logo depois a golpeia com um soco. Essa cena, que chega em um momento do filme em que o público já está pensando que as coisas não podiam piorar, mostra $o$ ataque às instituições mais caras da sociedade americana: a Família e a Igreja.

Quando, desesperada, Chris vai pedir ajuda à Igreja, mostra o caminho da maioria dos conservadores quando buscam justificativas para suas causas. Padre Karras, atendendo seu pedido, visita Regan e a encontra totalmente transformada. A imagem de Regan lasciva, inconveniente, agressiva e debochada não é diferente da imagem formada na cabeça dos pais que encontravam, quando chegavam a casa, filhos andrógenos, punks ou drogados.

Mas claro que essas situações não aconteciam em qualquer tipo de família. A onda conservadora que tomou conta dos Estados Unidos nos anos de 1970, com certeza, desaprovava a estrutura familiar vista na casa dos McNeil. Chris era fruto de todas as revoluções da década anterior: divorciada, trabalhava fora e mantinha uma relação hostil com o ex-marido.

No conflito dos velhos contra os novos, o conservadorismo ganha e a personalidade agressiva, contestadora e sexualizada de Regan é suplantada. A Igreja sofre danos, mas a Família se fortalece.

Visto no contexto do século XXI, O Exorcista perde um pouco da força. $\mathrm{Na}$ dinâmica deste século, onde crianças são geradas e criadas sem preocupação e os 
pais tentam se assemelhar aos filhos e não o contrário, as atrocidades ditas pelo demônio Pazuzu seriam recebidas com risos e palmas, não mais com terror.

\section{Conclusão}

A reapresentação da realidade nos filmes é um fato discutido e analisado desde as primeiras manifestações da sétima arte. A bem da verdade, todo filme é, em algum momento, um espelho de determinada realidade, mas nem todas essas representações são facilmente identificadas.

Quando analisamos a filmografia de terror das décadas de 1950, 1960 e 1970, é possível encontrar um padrão, um medo em comum que permeia a maioria das produções de cada período. Nos anos de 1950, o medo do terror externo e o constante clima de paranoia podiam ser vistos em filmes como Casei-me Com Um Monstro de Outro Espaço (1958), Invaders From Mars (1953) e Guerra dos Mundos (1953). A década de 1960 viu nascerem os splatter movies e o gore, que mostravam a violência e o sexo sem pudores para uma audiência que pedia mais contato com a realidade. O Bebê de Rosemary, embora lançado em 1968, marcou o período - que se estenderia por toda a década de 1970 - em que os filmes alertavam para o terror interno. O perigo próximo e inesperado apareceu em produções como A Cidade do Horror (1979), Halloween (1978) e O Iluminado (1980).

A representação dos temores da sociedade nos filmes não é necessariamente proposital. Jack Finney afirmou que seu livro The Body Snatchers (1955) nada tem a ver com a caça às bruxas, e William Friedkin certamente não pretendeu fazer um filme sobre o conflito entre pais e filhos, mas inconscientemente foi isso que eles fizeram, influenciados pela época em que trabalharam.

Os três filmes analisados anteriormente ganharam versões atualizadas nos anos 2000 e em todos os casos, as alegorias se adaptaram para assustar um público diferente das décadas de 1950, 1960 e 1970. A versão 2008 de Vampiros de Almas e de Os Invasores esquece a paranoia e o medo dos comunistas para se concentrar 
no perigo das guerras biológicas. O Exorcista: O início (2004) passa longe do terror que ocorre dentro de casa e aposta na ameaça que vem de fora para dentro, muito conveniente para a sociedade pós-11 de setembro de 2001. E, por fim, Madrugada dos Mortos (2004), remake do segundo filme da chamada "Trilogia dos Mortos" de George A. Romero, troca os mortos-vivos lentos, apáticos e "velhos", por uma horda de zumbis rápidos, ágeis e violentos.

A falta de intenção de usar alegorias para espelhar um determinado período, não as torna menos eficazes. A partir delas, é possível estreitar os laços entre o cinema e a audiência que interpreta os horrores cinematográficos de acordo com sua própria bagagem cultural e emocional.

\section{Scary movies as an allegory to the social horrors}

\section{Abstract}

The horror filmografy in the 30 years that comprehended the decades of 1950, 1960 e 1970, presented the fear getting closer to the America society and what the citizens did to remain safe. In the 1950's, the terror were far away, it came from outside to disturbe the social structures of America. In that context, Don Siegel's Invasion of The Body Snatchers put together all the insegurances of USA of surrendering to a communist regime and the paranoia that came with senator McCarthy's witch hunt. The decade of 1960's was all about revolutions. The new ideas overcoming the old ones is the core of George Romero's Night of The Living Dead, which presented the old-fashioned ideas as dead people who insisted in being active. In the 1970 's, the families were astonished when the horror was indeed in their own homes. A shock of generations took place and William Friedkin's The Exorcist represented it showing a mother who didn't know how to deal with her teenage daughter.

Keywords: Cinema. Terror. Allegory. United States. 


\section{Referências}

CAETANO, Dhiogo José. O homem diante da morte. Web Artigos, 2009. Disponível em: <http://www.webartigos.com/articles/21398/1/O-HOMEM-DIANTE-DAMORTE/pagina1.html>. Acesso em: 01 maio 2010.

COELHO, Cláudio Novaes Pinto. Publicidade: é possível escapar? São Paulo: Paulus, 2003.

DIRKS, Tim. Invasion of the body snatchers (1956). Film Site, Nova York, 2009. Disponível em: <http://www.filmsite.org/inva.html>. Acesso em: 30 maio 2009.

FERREIRA, Argemiro. Caça às bruxas: macartismo: uma tragédia americana. Porto Alegre: L\&PM, 1989.

KING, Stephen. Dança macabra. Rio de Janeiro: Francisco Alves, 1989.

SEVEN ages of rock: blank generation. Direção de Alastair Laurence. Londres, Inglaterra: BBC, 2007. Televisão. Documentário.

ROBINSON, Jennifer. Decades of drug use: data from the '60s and '70s. Gallup, Washington, 2002. Disponível em: <http://www.gallup.com/poll/ 6331/DecadesDrug-Use-Data-From-60s-70s.aspx>. Acesso em: 10 maio 2009.

SELLERS, Charles; MAY, Henry; MCMILLEN, Neil R. Uma reavaliação da história dos Estados Unidos. Rio de Janeiro: J. Zahar, 1990. 